УДК 631.4

\title{
Lead Content and Mobility \\ in Soils of the Republic of Tatarstan \\ under Different Land Use Types
}

\author{
Stanislav S. Ryazanov*, \\ Boris R. Grigoryan and Ilnaz A. Sahabiev \\ Research Institute for Problems of Ecology \\ and Mineral Wealth Use of Tatarstan Academy of Science \\ 28 Daurskaya Str., Kazan, 420087, Russia
}

Received 25.01.2017, received in revised form 04.02.2017, accepted 19.03.2019

\begin{abstract}
A geochemical survey of lead contamination was conducted for soils of the Republic of Tatarstan. 1164 topsoil samples were collected from different soil types. The effect of land use type (natural, agricultural, urbanized) on lead content and mobility in the topsoil was evaluated. The method of regression trees was used to study the structure of interactions between lead and other soil factors (organic matter, physical clay, $\mathrm{Fe}, \mathrm{Mn}, \mathrm{pH}$ ). The relative impacts of soil constituents on the content and mobility of lead in soils were assessed. The results showed that human activities were not the primary source of lead in the soils under natural and agricultural land use types. The correlations between content and mobility of lead and soil components are determined by the soil type and land use type.
\end{abstract}

Keywords: heavy metals, lead, $\mathrm{Pb}$, soil.

Citation: Ryazanov S.S., Grigoryan B.R., Sahabiev I.A. Lead content and mobility in soils of the Republic of Tatarstan under different land use types. J. Sib. Fed. Univ. Biol., 2019, 12(1), 101-116. DOI: 110.17516/1997-1389-0290.

(C) Siberian Federal University. All rights reserved

This work is licensed under a Creative Commons Attribution-NonCommercial 4.0 International License (CC BY-NC 4.0).

* Corresponding author E-mail address: RStanislav.soil@yandex.ru 


\title{
Содержание и подвижность свинца
}

в почвах Республики Татарстан

в условиях различных типов землепользования

\author{
С.С. Рязанов, Б.Р. Григорьян, И.А. Сахабиев \\ Институт проблем экологии и недропользования АН РТ \\ Россия, 420087, Казань, ул. Даурская, 28
}

Проведено геохимическое обследование загрязнения почв Республики Татарстан свинцом. На обследуемой территории отобрано 1164 образиа гумусовых горизонтов различных типов почв. Оченено влияние типов землепользования (естественный, сельскохозяйственный, урбанизированный) на содержание и подвижность свиниа в верхнем почвенном горизонте. $C$ помощью метода регрессионных деревьев изучена структура взаимосвязи свинца с почвенными компонентами (органическое вещество, физическая глина, Fe, $\mathrm{Mn}, \mathrm{pH}$ ), оценен относительный вклад влияния почвенных свойств на содержание и подвижность свинца в почвах. Результать работы показали, что свинец в почвах естественного и сельскохозяйственного типов землепользования имеет преимущественно неантропогенное происхождение. Корреляционные связи свинца с почвенными компонентами зависят как от типа почв, так и от типа землепользования.

Ключевые слова: тяжелые металль, свинеи, почвы.

\section{Введение}

Почва - наиболее важный и фундаментальный ресурс человеческого существования и развития. В последние десятилетия существует серьезная проблема загрязнения почв тяжелыми металлами. Изучение качества почвы не только позволяет оценить последствия человеческой деятельности, но также является необходимым этапом для устойчивого развития и сохранения истощаемых почвенных ресурсов ( $\mathrm{Li}$ et al., 2008). В настоящее время имеется острая необходимость в достоверной оценке качества почв для ряда практических задач: развитие органического земледелия и агротуризма, выбор участков, пригодных для сельскохозяйственной деятельности и урбанизации, определение стоимости рекультивации загрязненных участков и т.п. (Romic et al., 2007).
В современных условиях существуют два источника тяжелых металлов в почвах: естественный привнос в результате выветривания почвообразующих пород и антропогенные источники, такие как транспорт, предприятия промышленности, сельскохозяйственное использование земель (Esmaeili et al., 2014; Albanese et al., 2010). Непрерывное возрастание количества свинца в поверхностном слое как пахотных, так и необрабатываемых почв установлено в различных наземных экосистемах, и наблюдаемый баланс свинца показывает, что привнос этого элемента значительно превышает его вынос (КабатаПендиас, Пендиас, 1989). Данные о количестве антропогенных выбросов можно получить из официальных докладов или из оценок экспертов. Общие выбросы свинца для Евро- 
пы оцениваются в 35 и 8,6 кт/год для 1990 и 2003 гг. соответственно (Health..., 2007). Хотя вклад дорожного транспорта в выбросы свинца значительно снизился в связи с отказом от применения тетраэтилсвинца (с 85 \% по состоянию на 1990 г. до 6 \% в 2003 г.), опасность свинцового загрязнения по-прежнему остро стоит в индустриально развитых странах.

Изучение валового содержания тяжелых металлов в почвах позволяет оценить мощностьприродных и техногенных аномалий, однако масштабы поступления тяжелых металлов из почвы в растения и продукты питания определяются формами их соединений (Водяницкий, 2008). Формы нахождения свинца в разных типах почв могут значительно различаться. В высокогумусированных почвах свинец обладает слабой подвижностью за счет образования стабильных $\mathrm{Pb}^{2+}$-органических комплексов. В слабогумусированных почвах доминирующую роль в адсорбции свинца играют оксиды Mn и Fe (Bradl, 2004; Covelo et al., 2007). В то же время количественное изучение зависимости почвенного загрязнения тяжелыми металлами от параметров окружающей среды, особенно на мелких масштабах, значительно осложнено комплексностью почвенно-геохимических взаимодействий (Bou Kheir et al., 2014).

Цель работы - оценить зависимость содержания валовых и подвижных форм свинца в основных типах почв Республики Татарстан от почвенных компонентов и условий землепользования.

\section{Материалы и методы}

\section{Район исследования}

Исследование проводилось на территории Республики Татарстан, расположенной в западной части Российской Федерации (55²0'36,1"N; 5047'31,7"Е). Площадь обследованной территории составляет 67847 км².
Климат умеренно континентальный с небольшими различиями в пределах республики. Средняя годовая температура воздуха составляет 2-3,1 ${ }^{\circ} \mathrm{C}$, годовая сумма осадков - 460540 мм. Рельеф - возвышенная ступенчатая равнина, расчлененная густой сетью речных долин (Атлас..., 2005). Почвенный покров, согласно классификации 1977 г., представлен следующими основными типами: подзолистые (17\%), серые лесные (32,4\%), черноземы (39,7 \%), дерново-карбонатные (3,1\%). В пределах Республики выделяют несколько основных типов землепользования: земли сельскохозяйственного назначения (67 \%), земли населенных пунктов (5,2 \%), земли водного фонда (6,5 \%), земли особо охраняемых территорий и земли лесного фонда $(18,5 \%)$ (Александрова и др., 2012).

Главные потенциальные источники антропогенного загрязнения почв тяжелыми металлами - транспорт (до запрета применения тетраэтилсвинца в качестве антидетонирующей присадки к автомобильному топливу) и крупные промышленные предприятия (Водяницкий, 2008). Промышленный профиль республики определяют нефтегазохимический комплекс, машиностроительные предприятия, предприятия радио- и электроприборостроения. Главные промышленные центры республики - города Казань, Набережные Челны, Нижнекамск, Елабуга (Государственный..., 2015).

\section{Почвенные данные}

Всего на территории республики обследовано 1164 точек (рис. 1). Отбор проб проводился на расстоянии не менее 200 м от ближайшей дороги. Глубина отбора почвенных образцов составляла 0-20 см. Для 91 точки проводилось полное описание и отбор образцов по всему почвенному профилю. В почвенных образцах определялись следующие 


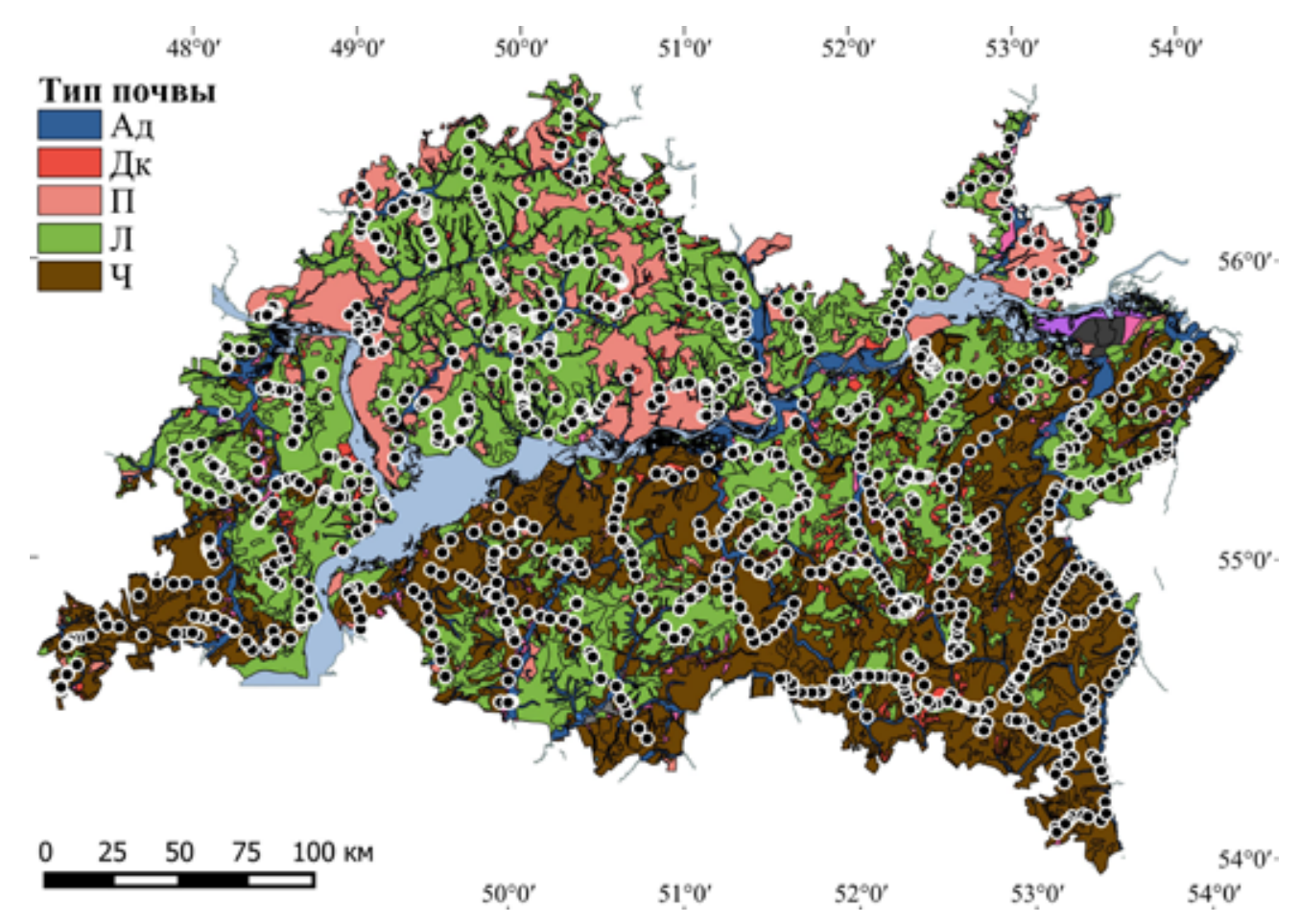

Рис. 1. Расположение точек отбора образцов на территории Республики Татарстан. Легенда почвенной карты (Атлас..., 2005): Ад - Аллювиальная дерновая насыщенная, Дк - Дерновая карбонатная, П Подзолистая, Л - Серая лесная, Ч - Чернозем

Fig. 1. Soil sampling locations on the territory of the Republic of Tatarstan. The soil map legend (Atlas..., 2005): Ад - alluvial sod alkalic soil, Дк - sod carbonate soil, П - podzol, Л - grey forest soil, Ч - chernozem

показатели: содержание гумуса по Тюрину, гранулометрический состав пипет-методом Качинского-Робинсона-Кехля с пробоподготовкой растиранием с пирофосфатом натрия, pH водной вытяжки потенциометрически (Ягодин и др., 1987). Определение валового содержания $\mathrm{Pb}, \mathrm{Fe}$ и $\mathrm{Mn}$ проводилось атомноабсорбционным методом после экстракции 5-молярной азотной кислотой (РД..., 1990). Содержание подвижных форм $\mathrm{Pb}$ определялось атомно-абсорбционным методом после экстракции ацетатно-аммонийным буферным раствором с рН 4,8 (РД..., 1991).

Тип землепользования присваивался согласно месту отбора почвенных образцов: (1) c/x - почвы сельскохозяйственного использования, (2) естественный - почвы, не используемые в с/х деятельности, и не старопахотные почвы (целинные и лесные почвы), (3) урбанизированный - образцы отобраны на территории городов. Распределение образцов по почвенным типам и условиям землепользования отражено в табл. 1. Подзолистые, аллювиальные дерновые насыщенные и аллювиальные луговые насыщенные почвы представлены, в основном, естественным типом землепользования (табл. 1). Большинство образцов черноземов, серых лесных и дерново-карбонатных почв представлено пахотными горизонтами земель $\mathrm{c} / \mathrm{x}$ назначения.

\section{Оченка регионального геохимического фона и расчет индексов загрязнения}

Оценка фонового уровня - необходимый этап в изучении загрязнения тяжелыми металлами. Несмотря на свою важность, эта задача 
Таблица 1. Количество образцов, отобранных в районах с разными типами почв и землепользования

Table 1. The number of soil samples collected in areas with different soil types and land use

\begin{tabular}{|l|c|c|c|}
\hline \multirow{2}{*}{ Тип почвы } & \multicolumn{3}{|c|}{ Тип землепользования } \\
\cline { 2 - 4 } & естественный & $\mathrm{c} / \mathrm{x}$ & урбанизированные \\
\hline Подзолистая & 38 & 8 & 0 \\
\hline Серая лесная & 155 & 367 & 0 \\
\hline Чернозем & 31 & 217 & 0 \\
\hline Дерново-карбонатная & 55 & 110 & 0 \\
\hline Аллювиальная дерновая насыщенная & 61 & 4 & 0 \\
\hline Аллювиальная луговая насыщенная & 29 & 7 & 82 \\
\hline Урбанозем & 0 & 0 & 0 \\
\hline
\end{tabular}

может вызывать определенные трудности, связанные с выбором значения, которое можно считать фоном. К тому же геохимический фоновый уровень является, скорее, диапазоном значений, а не неким абсолютным числом (Hawkes and Webb, 1962). В нашей работе использовался статистический (непрямой) метод медианного абсолютного отклонения (median absolute deviation, MAD), устойчивый к нарушениям нормальности распределения значений (Esmaeili et al., 2014). В этом случае диапазон фоновых значений оценивается как $\mathrm{Me} \pm 2 \mathrm{MAD}\left(\mathrm{MAD}=\mathrm{Me}\left(\left|\mathrm{X}_{\mathrm{i}}-\mathrm{Me}(\mathrm{X})\right|\right)\right)$.

Для оценки степени загрязнения в работе использовался однофакторный индекс загрязнения (Li et al., 2008). Однофакторный индекс загрязнения вычисляется как соотношение содержания тяжелого металла в почвенном образце $\left(\mathrm{C}_{\mathrm{i}}\right.$, мг/кг) к фоновому уровню $\left(\mathrm{S}_{\mathrm{i}}, \mathrm{мг/кГ)}\right.$ :

$$
\mathrm{P}_{\mathrm{i}}=\mathrm{C}_{\mathrm{i}} / \mathrm{S}_{\mathrm{i}}
$$

\section{Деревья регрессии и RandomForest}

Количественная оценка влияния почвенных компонентов и факторов почвообразования на содержание и подвижность тяжелых металлов необходима как для задач мониторинга, так и экологического моделирования.
В то же время подобный анализ значительно ограничен сложностью взаимодействий в почвенной системе (Bou Kheir et al., 2014). Деревья регрессии хорошо подходят для моделирования сложных, в том числе нелинейных, взаимодействий между исследуемым параметром и независимыми переменными (James et al., 2013). Результатом применения метода деревьев регрессии являются легко интерпретируемые модели, представляющие собой набор правил вида «если..., то...». Но при этом деревья регрессии обладают высоким параметром дисперсии, что означает, что существует множество реализаций дерева регрессии, дающих одинаковый результат, а добавление или удаление дополнительных данных способно коренным образом изменить структуру дерева (James et al., 2013).

Метод RandomForest, предложенный Breiman (2001), является расширенным вариантом бэггинга регрессионных деревьев и позволяет уменьшить дисперсность результатов ценой значительного уменьшения их интерпретируемости. Метод следует такому алгоритму: (1) исходный набор данных делится на $\mathrm{n}$ выборок методом бутстрапа; (2) для каждой выборки строится отдельное дерево регрессии, причем переменная, на основе которой производится разбиение, 
выбирается не из всех М доступных предикторов, а из $\mathrm{m}_{\text {try }}$ случайно выбранных; (3) итоговый результат получают после усреднения решений всех $\mathrm{n}$ деревьев. Метод RandomForest позволяет рассчитать значимость независимых переменных по уменьшению суммы квадратов ошибок (RSS) при использовании заданного предиктора (Liaw and Wiener, 2002).

В данной работе деревья регрессии использовались как инструмент разведочного анализа совокупного влияния почвенных компонентов и типа землепользования на содержание и подвижность свинца в почвах. Из-за нестабильности решения единственного дерева регрессии относительная значимость параметров оценена при помощи RandomForest.

\section{Использованное ПО}

Статистический анализ данных шел с помощью пакета R (R Core Team, 2016). Вариограммный анализ и пространственная интерполяция проведены при помощи пакета «gstat» (Pebesma, 2004). Метод деревьев регрессии применен при помощи пакета «tree» (Ripley, 2016); для метода RandomForest использована реализация в пакете «Randomforest» (Liaw and Wiener, 2002). Финальное оформление карт проводилось в геоинформационной системе QGIS (QGIS..., 2016).

\section{Результаты и обсуждение}

\section{Свинеи в почвах}

Описательная статистика рассматриваемых показателей представлена в табл. 2. Все показатели гумусовых горизонтов име-

Таблица 2. Концентрации металлов и физико-химические свойства почв

Table 2. Concentrations of metals and physical/chemical properties of soils

\begin{tabular}{|c|c|c|c|c|c|c|}
\hline Показатель & $\min$ & $\max$ & median & mean* & $\mathrm{cV}^{*}$ & Shapiro test \\
\hline \multicolumn{7}{|c|}{ горизонт А (n=1164) } \\
\hline $\mathrm{Pb}_{\text {вал. }}($ мГ/кг) & 0,7 & 65,6 & 11,6 & 11,7 & 33,6 & $\mathrm{~W}=0,83, \mathrm{p}<0,05$ \\
\hline $\mathrm{Pb}_{\text {подв. }}($ мГ/кГ) & 0,0 & 18,6 & 0,8 & 0,8 & 100,3 & $\mathrm{~W}=0,46, \mathrm{p}<0,05$ \\
\hline $\mathrm{Pb}_{\text {подв. }} / \mathrm{Pb}_{\text {вал. }}$ & 0,00 & 0,86 & 0,07 & 0,08 & 84,66 & $\mathrm{~W}=0,73, \mathrm{p}<0,05$ \\
\hline Гумус (\%) & 0,2 & 16,2 & 5,5 & 5,4 & 50,1 & $\mathrm{~W}=0,98, \mathrm{p}<0,05$ \\
\hline Физ. глина (\%) & 3,4 & 73,6 & 41,3 & 41,2 & 30,8 & $\mathrm{~W}=0,98, \mathrm{p}<0,05$ \\
\hline рН водн. & 4,8 & 8,8 & 7,0 & 7,0 & 10,2 & $\mathrm{~W}=0,98, \mathrm{p}<0,05$ \\
\hline $\mathrm{Fe}_{\text {вал. }}($ мг/кг) & 775,0 & 75340,0 & 17760,0 & 20325,8 & 45,0 & $\mathrm{~W}=0,81, \mathrm{p}<0,05$ \\
\hline $\mathrm{Mn}_{\text {вал. }}(\mathrm{M} \Gamma / \kappa г)$ & 49,8 & 3344,0 & 609,0 & 665,4 & 51,4 & $\mathrm{~W}=0,85, \mathrm{p}<0,05$ \\
\hline \multicolumn{7}{|c|}{ горизонты В+BC (n=91) } \\
\hline $\mathrm{Pb}_{\text {вал. }}($ мГ/кг $)$ & 2,6 & 21,4 & 10,7 & 10,9 & 34,0 & $\mathrm{~W}=0,99, \mathrm{p}>0,05$ \\
\hline $\mathrm{Pb}_{\text {подв. }}($ МГ/кГ $)$ & 0,0 & 3,6 & 0,9 & 1,1 & 69,5 & $\mathrm{~W}=0,87, \mathrm{p}<0,05$ \\
\hline $\mathrm{Pb}_{\text {подв. }} / \mathrm{Pb}_{\text {вал. }}$ & 0,00 & 0,36 & 0,09 & 0,11 & 69,44 & $\mathrm{~W}=0,90, \mathrm{p}<0,05$ \\
\hline Физ. глина (\%) & 10,7 & 7,6 & 39,4 & 40,1 & 43,5 & $\mathrm{~W}=0,97, \mathrm{p}>0,05$ \\
\hline pН водн. & 4,9 & 8,9 & 8,0 & 7,7 & 11,4 & $\mathrm{~W}=0,86, \mathrm{p}<0,05$ \\
\hline $\mathrm{Fe}_{\text {вал. }}(\mathrm{M \Gamma} / \mathrm{К})$ & 4664,0 & 76480,0 & 20090,0 & 24130,0 & 59,1 & $\mathrm{~W}=0,86, \mathrm{p}<0,05$ \\
\hline $\mathrm{Mn}_{\text {вал. }}(\mathrm{M \Gamma} / \kappa \Gamma)$ & 61,5 & 1933,0 & 430,6 & 498,5 & 60,3 & $\mathrm{~W}=0,75, \mathrm{p}<0,05$ \\
\hline
\end{tabular}

* Среднее и коэффициент вариации показателей гумусовых горизонтов рассчитаны после полигональной декластеризации. 
ют ненормальное распределение, поэтому для дальнейшего анализа использовались непараметрические критерии. Значения валового свинца имеют несколько потенциальных выбросов, что, однако, объясняется тем, что данные образцы отобраны на территории крупных городов. Высокие значения коэффициентов вариации всех почвенных параметров как верхних, так и нижних горизонтов связаны с неоднородностью почвенноклиматических условий территории.

Поскольку в схеме отбора почвенных образцов наблюдается выраженная кластеризованность (особенно сильно точки сгруппированы на территории крупных городов (рис. 1)), то для получения несмещенных оценок среднего и дисперсии использован метод полигональной декластеризации значений (Isaaks and Srivastava, 1989). По содержанию валовой формы свинца лишь 0,6 \% образцов превышают 32 мг/кг - предельно допустимую концентрацию свинца в почвах, установленную стандартами Российской Федерации (ГН 2.1.7.2041-06).

При сравнении верхних горизонтов почв с подповерхностными выявлена значимая корреляция по содержанию валовых и подвижных форм свинца $\left(\mathrm{r}_{(\mathrm{Pb} \text { вал.) }}=0,56, \mathrm{r}_{\text {(Рь подв.) }}=0,5\right)$, что позволяет судить об отсутствии значительного экзогенного привноса этого элемента. Остальные почвенные характеристики также имеют относительно сильные значения корреляции: $\mathrm{r}_{\text {(Физ. гл.) }}=0,63, \mathrm{r}_{(\mathrm{pH})}=0,6, \mathrm{r}_{\text {(Fе вал.) }}=0,63$, $\mathrm{r}_{\text {(Мп вал.) }}=0,47$.

Для оценки пространственного распределения концентрации свинца в верхнем почвенном горизонте проведена интерполяция значений методом ординарного кригинга (Goovaerts, 1997). Пространственная структура значений описывалась изотропной сферической вариограммой (nugget=11,43, range $=44121,7$, partial sill $=8,89)$. Соотношение наггет-к-порогу равно 0,56 и говорит о средней силе пространственной структуры, что связано, однако, с малой плотностью точек отбора образцов (Cambardella et al., 1994). Распределение свинца в почвах Татарстана относительно неоднородно, а области повышенных значений приурочены к наиболее крупным городам Республики: Казань - в северо-западной части, Набережные Челны - в северо-восточной части и Бугульма в юго-восточной части (рис. $2 a$ ). Анализ по Краскелу-Уоллису показал отсутствие значимых различий по общему содержанию и подвижности свинца для образцов городских почв, отобранных в различных населенных пунктах (табл. 3).

Почвенный тип, согласно генетической почвенной классификации, определяет почвы, развивающиеся в однотипно-сопряженных биологических, климатических и гидрологических условиях, на определенной группе почвообразующих пород (Кауричев, 1989). Будучи интегральным показателем условий окружающей среды, тип почвы также определяет содержание и подвижность свинца в почвах. Непараметрический дисперсионный анализ по Краскелу-Уоллису показал значимые различия между разными типами почв как по валовому содержанию, так и по подвижности свинца, определяемой как соот-

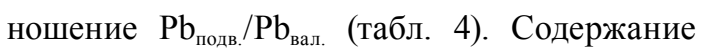
валового свинца в почвах возрастает в ряду: Аллювиальная дерновая насыщенная $>$ Подзолистая > Чернозем > Аллювиальная луговая насыщенная > Дерново-карбонатная $>\mathrm{Ce}$ рая лесная $>$ Урбанозем.

Влияние типа землепользования на валовое содержание свинца в почвах наблюдается лишь для черноземов $(\mathrm{W}=4536, \mathrm{p}$-adj=0,007): образцы, отобранные из пахотных горизонтов с/х угодий, обладают более высокой концентрацией свинца (среднее=10,9 мг/кг), чем 


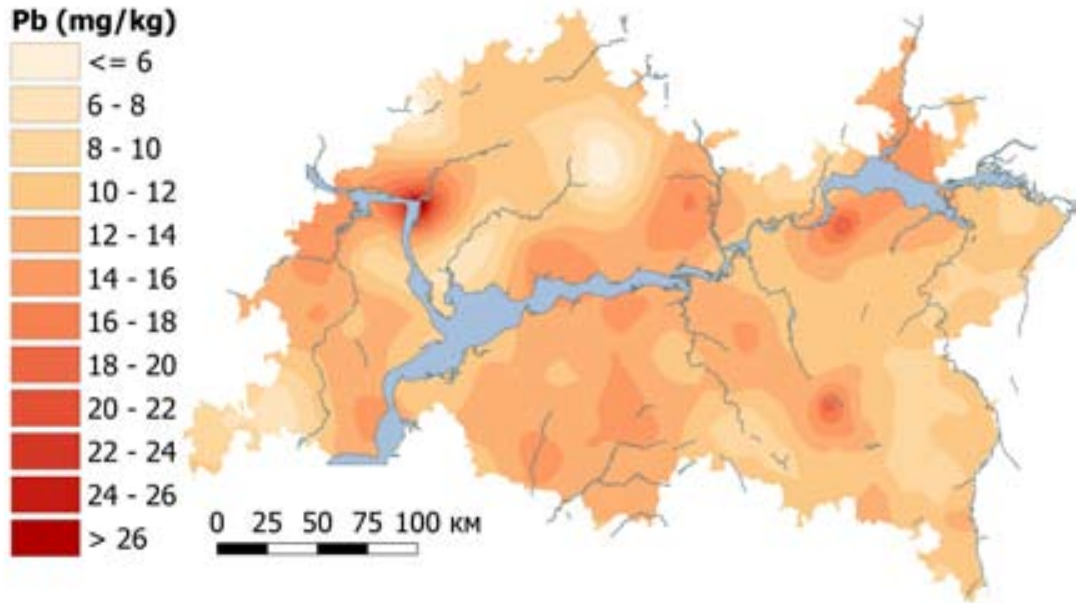

Pi
$\square$
$\quad 0-1$
$1-2$

$2-3$

$\quad 3-4$

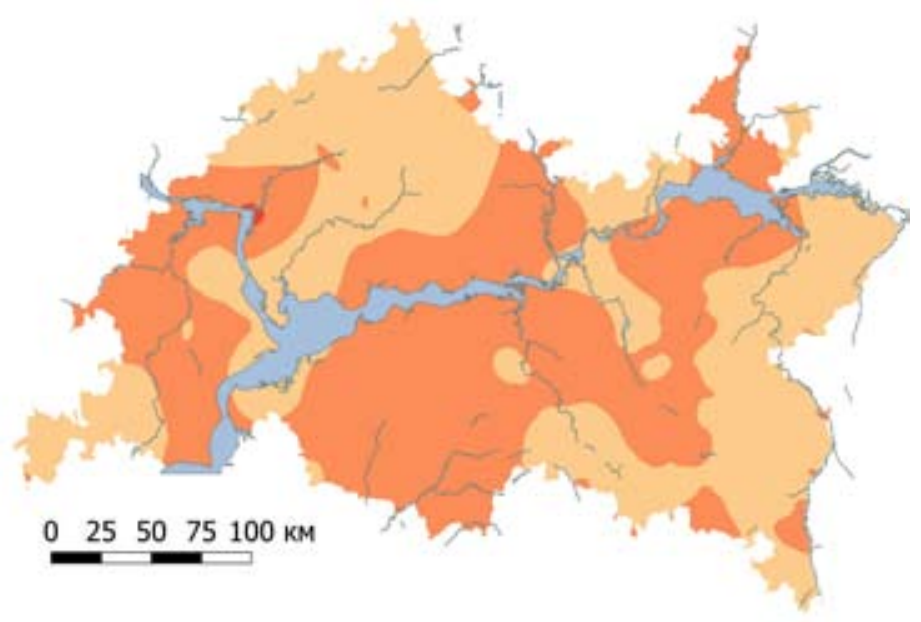

Рис. 2. Пространственное распределение значений валового содержания свинца в гумусовом горизонте (a) и индекса загрязнения свинцом (b) на территории Республики Татарстан

Fig. 2. Spatial distribution of total lead content in topsoil (a) and lead pollution index (b) on the territory of the Republic of Tatarstan

Таблица 3. Сравнение городских почв по содержанию свинца и индексу загрязнения

Table 3. Comparison of urban soils by lead content and pollution index

\begin{tabular}{|c|c|c|c|c|c|c|c|}
\hline \multirow{2}{*}{ Нас. пункт } & \multicolumn{2}{|c|}{$\mathrm{Pb}_{\text {вал. }}$} & \multicolumn{2}{|c|}{$\mathrm{Pb}_{\text {вал. }} / \mathrm{Pb}_{\text {подв. }}$} & \multicolumn{3}{|c|}{$\mathrm{P}_{\mathrm{i}}$} \\
\hline & $\mathrm{Me}$ & $\mathrm{K}-\mathrm{W}$ test & $\mathrm{Me}$ & $\mathrm{K}-\mathrm{W}$ test & $\min$ & $\overline{P_{l}}$ & $\max$ \\
\hline Казань & 17,5 & \multirow{4}{*}{$\mathrm{p}>0,05$} & 0,16 & \multirow{4}{*}{$\mathrm{p}>0,05$} & 0,3 & 2,0 & 5,7 \\
\hline Н. Челны & 17,8 & & 0,08 & & 1,2 & 1,8 & 3,0 \\
\hline Зеленодольск & 12,5 & & 0,10 & & 0,9 & 1,3 & 2,0 \\
\hline Альметьевск & 18,5 & & 0,10 & & 1,1 & 1,7 & 2,9 \\
\hline
\end{tabular}


образцы гумусовых горизонтов не с/х почв (среднее $=9,2 \mathrm{мг} / к г$ ).

При анализе различий подтипов в пределах отдельных почвенных типов значимые различия по содержанию $\mathrm{Pb}$ наблюдаются только для выщелоченных и типичных черноземов естественного землепользования и оподзоленных черноземов $\mathrm{c} / \mathrm{x}$ типа землепользования (табл. 5).

\section{Региональный геохимический фон} и оченка загрязнения почв

Для расчета регионального фонового уровня свинца использованы образцы зо-

Таблица 4. Содержание и подвижность свинца в разных типах почв

Table 4. Lead content and mobility in different soil types

\begin{tabular}{|c|c|c|c|c|c|c|c|c|c|c|}
\hline \multirow{2}{*}{ Тип } & \multicolumn{5}{|c|}{$\mathrm{Pb}_{\text {вал. }}$} & \multicolumn{5}{|c|}{$\mathrm{Pb}_{\text {подв. }} / \mathrm{Pb}_{\text {вал. }}$} \\
\hline & $\min$ & $\mathrm{m}$ & $\mathrm{Me}$ & $\max$ & $\mathrm{cv}$ & $\min$ & $\mathrm{m}$ & $\mathrm{Me}$ & $\max$ & $\mathrm{cv}$ \\
\hline Подзолистая & 1,2 & 10,0 & 10,1 & 18,4 & 44,3 & 0,00 & 0,09 & 0,08 & 0,51 & 84,3 \\
\hline Серая лесная & 0,7 & 11,6 & 11,7 & 20,7 & 27,0 & 0,00 & 0,07 & 0,06 & 0,86 & 83,1 \\
\hline Чернозем & 0,8 & 10,8 & 11,0 & 22,8 & 30,4 & 0,00 & 0,07 & 0,06 & 0,34 & 78,2 \\
\hline Дерново-карбонатная & 3,1 & 11,8 & 11,6 & 20,5 & 30,0 & 0,00 & 0,08 & 0,07 & 0,45 & 83,9 \\
\hline $\begin{array}{l}\text { Аллювиальная дерновая } \\
\text { насыщенная }\end{array}$ & 3,0 & 10,3 & 10,0 & 17,7 & 32,4 & 0,00 & 0,12 & 0,09 & 0,55 & 78,8 \\
\hline $\begin{array}{l}\text { Аллювиальная луговая } \\
\text { насыщенная }\end{array}$ & 5,3 & 11,4 & 11,5 & 20,4 & 30,2 & 0,00 & 0,10 & 0,09 & 0,27 & 58,4 \\
\hline Урбанозем & 3,1 & 19,6 & 18,0 & 65,6 & 48,2 & 0,01 & 0,13 & 0,09 & 0,45 & 75,27 \\
\hline Kruskal-Wallis test, $\mathrm{p}$-value & \multicolumn{5}{|c|}{$<0,05$} & \multicolumn{5}{|c|}{$<0,05$} \\
\hline
\end{tabular}

Таблица 5. Сравнение почвенных подтипов по содержанию валового свинца

Table 5. Comparison of soil subtypes by total lead content

\begin{tabular}{|c|c|c|c|c|c|c|c|}
\hline \multirow{2}{*}{ Тип } & \multirow{2}{*}{ Подтип } & \multicolumn{3}{|c|}{ естеств. } & \multicolumn{3}{|c|}{$\mathrm{c} / \mathrm{x}$} \\
\hline & & $\mathrm{n}$ & $\mathrm{Me}$ & $\mathrm{K}-\mathrm{W}$ test & $\mathrm{n}$ & $\mathrm{Me}$ & $\mathrm{K}-\mathrm{W}$ test \\
\hline Подзолистая & Дерново-подзолистая & 38 & 8,5 & - & 8 & 10,7 & - \\
\hline \multirow{3}{*}{ Серая лесная } & Светло-серая лесная & 14 & 11,9 & \multirow{3}{*}{0,67} & 13 & 10,3 & \multirow{3}{*}{0,24} \\
\hline & Серая лесная & 71 & 12,0 & & 197 & 11,5 & \\
\hline & Темно-серая лесная & 70 & 12,8 & & 157 & 12,2 & \\
\hline \multirow{4}{*}{ Чернозем } & Оподзоленный & 2 & - & \multirow{4}{*}{0,04} & 13 & 13,5 & \multirow{4}{*}{$<0,05$} \\
\hline & Выщелоченный & 14 & 9,5 & & 124 & 10,8 & \\
\hline & Типичный & 12 & 6,7 & & 78 & 10,9 & \\
\hline & Слаборазвитый & 3 & - & & 2 & - & \\
\hline \multirow{3}{*}{ Дерново-карбонатная } & Выщелоченные & 28 & 12,3 & \multirow{3}{*}{0,11} & 55 & 11,6 & \multirow{3}{*}{0,93} \\
\hline & Оподзоленные & 5 & 14,7 & & 2 & - & \\
\hline & Типичные & 22 & 12,6 & & 53 & 11,6 & \\
\hline $\begin{array}{l}\text { Аллювиальная дерновая } \\
\text { насыщенная }\end{array}$ & - & 61 & 10,1 & - & 4 & 8,2 & - \\
\hline $\begin{array}{l}\text { Аллювиальная луговая } \\
\text { насыщенная }\end{array}$ & - & 29 & 11,7 & - & 7 & 9,7 & - \\
\hline
\end{tabular}


нальных типов почв (подзолистые, серые лесные, черноземы). Незональные типы почв (дерново-карбонатные, аллювиальные дерновые насыщенные) были исключены для устранения влияния аномальных зон, связанных с выходом карбонатных пород и привноса с аллювиальными отложениями. Из-за малого количества образцов, отобранных из нижних горизонтов зональных почв $(n=29)$, оценка проводилась по образцам гумусовых горизонтов.

Региональный фоновый уровень свинца в почвах, рассчитанный по образцам гуму-

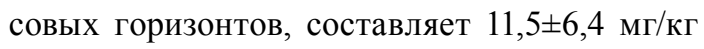
(Me $\pm 2 \mathrm{MAD})$. Верхний порог регионального фона составляет 17,9 мг/кг (Me+2MAD) и равен $\mathrm{Me}+2 \mathrm{MAD}$ подповерхностных горизонтов, что служит дополнительным подтверждением адекватности оценки фона. Полученное значение $\mathrm{Me} \pm 2 \mathrm{MAD}$ не противоречит региональным нормативам качества почв, утвержденных для Республики Татарстан (Иванов, 2016; Региональные..., 2015). Рассчитанный региональный фон свинца в почвах незначительно превышает медианное значение в почвах мира (17 мг/кг) и кларк свинца в земной коре (16 мг/кг) (Reimann and de Caritat, 1998; Добровольский, 2003).

На основе фонового значения рассчитан индекс загрязнения $\left(\mathrm{P}_{\mathrm{i}}\right)$ почв свинцом.
Региональное загрязнение территории Республики неоднородно - 46,9 \% от общей площади Республики имеет индекс загрязнения $\mathrm{P}_{\mathrm{i}} \leq 1$ и характеризуется как чистая, $52,9 \%$ площади с индексом $1<\mathrm{P}_{\mathrm{i}} \leq 2$ характеризуется как потенциально загрязненная, площадь с индексом $\mathrm{P}_{\mathrm{i}}>2$ занимает менее $1 \%$ (рис. $2 b$ ). Наибольшее загрязнение наблюдается для образцов, отобранных на территории г. Казани и Набережных Челнов: индекс загрязнения $\mathrm{Pi}$ достигает 5,7 (высокий уровень загрязнения) и 3,0 (средний уровень загрязнения) соответственно (табл. 3).

\section{Влияние типа землепользования}

Сельскохозяйственный и естественный типы землепользования, помимо отсутствий различий в содержании и подвижности свинца в большинстве типов почв, показывают и схожие распределения значений индекса загрязнения (табл. 6). Приведенные результаты также свидетельствуют об отсутствии антропогенного привноса свинца в почвы, связанного непосредственно с сельскохозяйственной деятельностью.

Несмотря на отсутствие различий между двумя типами землепользования по содержанию и подвижности свинца в большинстве типов почв, с/х деятельность влияет на струк-

Таблица 6. Процентное распределение проб по градациям значений индекса загрязнения свинцом на территориях с разными типами землепользования

Table 6. Percentage distribution of soil samples based on the gradations of lead pollution indices in areas with different types of land use

\begin{tabular}{|l|c|c|c|c|c|c|}
\hline \multirow{2}{*}{\multicolumn{1}{|c|}{ Тип землепользования }} & \multicolumn{7}{|c|}{ Индекс загрязнения (Pi) } \\
\cline { 2 - 9 } & $0<\mathrm{P}_{\mathrm{i}} \leq 1$ & $1<\mathrm{P}_{\mathrm{i}} \leq 2$ & $2<\mathrm{P}_{\mathrm{i}} \leq 3$ & $3<\mathrm{P}_{\mathrm{i}} \leq 4$ & $4<\mathrm{P}_{\mathrm{i}} \leq 5$ & $5<\mathrm{P}_{\mathrm{i}}$ \\
\hline Все типы & 47,8 & 50,4 & 1,5 & 0,1 & 0,1 & 0,1 \\
\hline Естественный & 49,6 & 50,1 & 0,3 & 0,0 & 0,0 & 0,0 \\
\hline Сельскохозяйственный & 50,9 & 49,1 & 0,0 & 0,0 & 0,0 & 0,0 \\
\hline Урбанизированный & 8,1 & 64,9 & 23,0 & 1,4 & 1,4 & 1,4 \\
\hline
\end{tabular}


туру геохимических связей свинца с другими почвенными компонентами, что может быть объяснено изменением физико-химических свойств почв, их водного и воздушного режимов. В табл. 7 представлены результаты корреляционного анализа содержания и подвижности свинца в гумусовых и пахотных горизонтах.
В подзолистых почвах с естественным типом землепользования свинец проявляет сидерофильные и манганофильные свойствасодержание свинца возрастает с увеличением содержания гидроксидов и оксидов железа и оксидов марганца, главных сорбентов тяжелых металлов в малогумусных почвах (Водяницкий, 2008). Такому поведению свинца

Таблица 7. Коэффициенты корреляции содержания и подвижности свинца с показателями свойств почвы

Table 7. Correlations between total content and mobility of lead and soil constituents

\begin{tabular}{|c|c|c|c|c|c|c|c|c|}
\hline \multicolumn{9}{|c|}{ Подзолистая } \\
\hline $\mathrm{n}$ & & $\mathrm{Pb}_{\text {вал. }}$ & $\mathrm{Pb}_{\text {подв. }}$ & Гумус & Физ. глина & pН водн. & $\mathrm{Fe}_{\text {вал. }}$ & $\mathrm{Mn}_{\text {вал. }}$ \\
\hline 1 & 2 & 3 & 4 & 5 & 6 & 7 & 8 & 9 \\
\hline \multirow{2}{*}{38} & $\mathrm{~Pb}_{\text {вал. }}$ & 1 & 0,6 & 0,29 & 0,24 & 0,22 & $\mathbf{0 , 3 7}$ & 0,41 \\
\hline & $\mathrm{Pb}_{\text {подв. }} / \mathrm{Pb}_{\text {вал. }}$ & $-0,12$ & 0,63 & 0,08 & 0,28 & 0,13 & 0,26 & $-0,13$ \\
\hline \multirow{2}{*}{8} & $\mathrm{~Pb}_{\text {вал. }}$ & 1 & 0,62 & $-0,12$ & $-0,33$ & 0,43 & $-0,98$ & 0,21 \\
\hline & $\mathrm{Pb}_{\text {подв. }} / \mathrm{Pb}_{\text {вал. }}$ & 0,07 & 0,76 & 0,74 & 0,02 & $-0,29$ & $-0,12$ & $-0,33$ \\
\hline \multicolumn{9}{|c|}{ Серая лесная } \\
\hline $\mathrm{n}$ & & $\mathrm{Pb}_{\text {вал. }}$ & $\mathrm{Pb}_{\text {подв. }}$ & Гумус & Физ. глина & pН водн. & $\mathrm{Fe}_{\text {вал. }}$ & $\mathrm{Mn}_{\text {вал. }}$ \\
\hline \multirow{2}{*}{155} & $\mathrm{~Pb}_{\text {вал. }}$ & 1 & 0,23 & 0,22 & 0,07 & 0,02 & 0,1 & 0,13 \\
\hline & $\mathrm{Pb}_{\text {подв. }} / \mathrm{Pb}_{\text {вал. }}$ & $-0,19$ & $\mathbf{0 , 8 8}$ & 0,05 & $-0,09$ & $-0,17$ & $-0,19$ & $-0,25$ \\
\hline \multirow{2}{*}{367} & $\mathrm{~Pb}_{\text {вал. }}$ & 1 & 0,21 & 0,1 & 0,27 & $\mathbf{0 , 1 8}$ & 0,23 & 0,16 \\
\hline & $\mathrm{Pb}_{\text {подв. }} / \mathrm{Pb}_{\text {вал. }}$ & $-0,31$ & 0,81 & 0,05 & $-0,02$ & $-0,03$ & $-0,03$ & $-0,05$ \\
\hline \multicolumn{9}{|c|}{ Чернозем } \\
\hline $\mathrm{n}$ & & $\mathrm{Pb}_{\text {вал. }}$ & $\mathrm{Pb}_{\text {подв. }}$ & Гумус & Физ. глина & pН водн. & $\mathrm{Fe}_{\text {вал. }}$ & $\mathrm{Mn}_{\text {вал. }}$ \\
\hline \multirow{2}{*}{31} & $\mathrm{~Pb}_{\text {вал. }}$ & 1 & 0,22 & 0,08 & $-0,18$ & $-0,02$ & $\mathbf{0 , 3 7}$ & 0 \\
\hline & $\mathrm{Pb}_{\text {подв. }} / \mathrm{Pb}_{\text {вал. }}$ & $-0,35$ & 0,78 & 0,24 & $-0,02$ & 0,16 & 0,07 & 0,11 \\
\hline \multirow{2}{*}{217} & $\mathrm{~Pb}_{\text {вал. }}$ & 1 & 0,19 & $-0,12$ & 0,14 & 0,09 & 0,1 & 0,04 \\
\hline & $\mathrm{Pb}_{\text {подв. }} / \mathrm{Pb}_{\text {вал. }}$ & $-0,23$ & $\mathbf{0 , 8 8}$ & 0,09 & $-0,1$ & 0,11 & 0,01 & 0,05 \\
\hline \multicolumn{9}{|c|}{ Дерново-карбонатная } \\
\hline $\mathrm{n}$ & & $\mathrm{Pb}_{\text {вал. }}$ & $\mathrm{Pb}_{\text {подв. }}$ & Гумус & Физ. глина & pН водн. & $\mathrm{Fe}_{\text {вал. }}$ & $\mathrm{Mn}_{\text {вал. }}$ \\
\hline \multirow{2}{*}{55} & $\mathrm{~Pb}_{\text {вал. }}$ & 1 & $\mathbf{0 , 3 2}$ & 0,15 & 0,22 & $-0,05$ & $\mathbf{0 , 2 8}$ & 0,09 \\
\hline & $\mathrm{Pb}_{\text {подв. }} / \mathrm{Pb}_{\text {вал. }}$ & $-0,1$ & $\mathbf{0 , 8 7}$ & $-0,37$ & $-0,07$ & 0,45 & 0,03 & $-0,24$ \\
\hline \multirow{2}{*}{110} & $\mathrm{~Pb}_{\text {вал. }}$ & 1 & $-0,11$ & 0,04 & 0,29 & $-0,2$ & $\mathbf{0 , 1 9}$ & $-0,07$ \\
\hline & $\mathrm{Pb}_{\text {подв. }} / \mathrm{Pb}_{\text {вал. }}$ & $-0,38$ & 0,95 & 0,16 & $-0,02$ & $\mathbf{0 , 2 8}$ & $-0,12$ & 0,01 \\
\hline \multicolumn{9}{|c|}{ Аллювиальная дерновая насыщенная } \\
\hline $\mathrm{n}$ & & $\mathrm{Pb}_{\text {вал. }}$ & $\mathrm{Pb}_{\text {подв. }}$ & Гумус & Физ. глина & pН водн. & $\mathrm{Fe}_{\text {вал. }}$ & $\mathrm{Mn}_{\text {вал. }}$ \\
\hline \multirow{2}{*}{61} & $\mathrm{~Pb}_{\text {вал. }}$ & 1 & 0,08 & $-0,1$ & 0,09 & $-0,01$ & 0,14 & 0,08 \\
\hline & $\mathrm{Pb}_{\text {подв. }} / \mathrm{Pb}_{\text {вал. }}$ & $-0,34$ & 0,86 & 0,1 & 0 & 0,28 & 0,06 & 0,16 \\
\hline \multirow{2}{*}{4} & $\mathrm{~Pb}_{\text {вал. }}$ & - & - & - & - & - & - & - \\
\hline & $\mathrm{Pb}_{\text {подв. }} / \mathrm{Pb}_{\text {вал. }}$ & - & - & - & - & - & - & - \\
\hline
\end{tabular}


Продолжение таблицы 7

Continued Table 7

\begin{tabular}{|c|c|c|c|c|c|c|c|c|}
\hline 1 & 2 & 3 & 4 & 5 & 6 & 7 & 8 & 9 \\
\hline \multicolumn{9}{|c|}{ Аллювиальная луговая насыщенная } \\
\hline $\mathrm{n}$ & & $\mathrm{Pb}_{\text {вал. }}$ & $\mathrm{Pb}_{\text {подв. }}$ & Гумус & Физ. глина & рН водн. & $\mathrm{Fe}_{\text {вал. }}$ & $\mathrm{Mn}_{\text {вал. }}$ \\
\hline \multirow{2}{*}{29} & $\mathrm{~Pb}_{\text {вал. }}$ & 1 & 0,07 & $\mathbf{0 , 5 6}$ & $\mathbf{0 , 5 3}$ & $-0,18$ & 0,16 & 0,28 \\
\hline & $\mathrm{Pb}_{\text {подв. }} / \mathrm{Pb}_{\text {вал. }}$. & $-0,48$ & $\mathbf{0 , 7 8}$ & $-0,16$ & $-0,23$ & 0,66 & $-0,1$ & 0,15 \\
\hline \multirow{2}{*}{7} & $\mathrm{~Pb}_{\text {вал. }}$ & 1 & 0,23 & 0,5 & 0,74 & $-0,25$ & 0,41 & 0,41 \\
\hline & $\mathrm{Pb}_{\text {подв. }} / \mathrm{Pb}_{\text {вал. }}$ & $-0,7$ & 0,46 & $-0,43$ & $-0,86$ & 0,07 & $-0,89$ & $-0,54$ \\
\hline \multicolumn{9}{|c|}{ Урбанозем } \\
\hline $\mathrm{n}$ & & $\mathrm{Pb}_{\text {вал. }}$ & $\mathrm{Pb}_{\text {подв. }}$ & Гумус & Физ. глина & pH водн. & $\mathrm{Fe}_{\text {вал. }}$ & $\mathrm{Mn}_{\text {вал. }}$ \\
\hline \multirow{2}{*}{82} & $\mathrm{~Pb}_{\text {вал. }}$ & 1 & 0,66 & $\mathbf{0 , 3 1}$ & 0,17 & $\mathbf{0 , 3 2}$ & 0,14 & 0,11 \\
\hline & $\mathrm{Pb}_{\text {подв. }} / \mathrm{Pb}_{\text {вал. }}$ & 0,36 & 0,91 & $-0,19$ & $-0,31$ & 0,44 & $-0,28$ & $-0,26$ \\
\hline
\end{tabular}

Цветом выделены разные типы землепользования: зеленый - естественный, желтый - c/х почвы, красный - городские почвы. Жирным выделены значимые коэффициенты корреляции (p.adj<0.05).

также способствует легкий гранулометрический состав гумусовых горизонтов - среднее содержание физический глины равно 19,8 \%. Малое количество образцов подзолистых почв $\mathrm{c} / \mathrm{x}$ использования $(\mathrm{n}=8)$ не позволяет провести достоверный корреляционный анализ (табл. 1).

В серых лесных почвах естественного землепользования свинец проявляет выраженные органофильные свойства. В c/x почвах отсутствует значимая зависимость от содержания органического вещества, но наблюдаются положительные корреляции с гранулометрическим составом и валовым содержанием железа и марганца (табл. 7). Подобные различия геохимических связей свинца в почвах различного землепользования, при отсутствии различий в валовом содержании, могут быть объяснены значительным снижением содержания органического вещества в с/х серых лесных почвах (4,3\%) в сравнении с естественными (6,5\%). По соотношению $\mathrm{Pb}_{\text {подв. }} / \mathrm{Pb}_{\text {вал. }}$ естественные и $\mathrm{c} / \mathrm{x}$ серые лесные почвы не имеют значимых различий $(\mathrm{W}=27126, \mathrm{p}=0,4)$, однако, в естественных почвах в отличии от пахотных наблю- дается слабая отрицательная зависимость от реакции среды и содержания железа и марганца.

В черноземах, несмотря на большое содержание гумуса (естественные - 7,67 \%, c/x 7,57 \%), свинец не проявляет органофильных свойств. В естественных черноземах свинец проявляет сидерофильные свойства, в с/x черноземах наблюдается положительная зависимость только от содержания физической глины.

В дерново-карбонатных почвах содержание свинца положительно связано с содержанием валовых форм железа и гранулометрическим составом. Подвижность свинца в гумусовом горизонте естественных дерново-карбонатных почв имеет отрицательную зависимость от содержания органического вещества. Содержание валового свинца в аллювиальных луговых насыщенных почвах имеет положительную корреляцию с содержанием органического вещества и физической глины в гумусовом горизонте.

В городских почвах свинец проявляет органофильные свойства. Подвижность свин- 
ца уменьшается с увеличением содержания физической глины и валовых форм железа и марганца.

\section{Структура геохимических связей}

Корреляционный анализ показал, что взаимодействие свинца с почвенными компонентами имеет сложную структуру, которая к тому же различается как между почвенными типами, так и между типами землепользования. Метод деревьев регрессии позволит оценить структуру почвенно-геохимических связей, а метод RandomForest - количественно оценить относительную значимость почвенных параметров в определении валового содержания и подвижности свинца в почвах.

Валовое содержание свинца в почвах в первую очередь зависит от антропогенной нагрузки, определяемой типом землепользования. В естественных и с/х почвах, где, как было показано выше, присутствует лишь незначительный антропогенный привнос свинца, главными параметрами, определяющими валовую концентрацию свинца в почвах, являются содержания $\mathrm{Fe}$ и $\mathrm{Mn}$ (рис. $3 a, b$ ). Совместно с низкими значениями индекса загрязнения (табл. 6) такая зависимость позволяет сделать заключение, что содержание свинца в исследованных почвах главным образом обусловлено естественными источниками. В городских почвах, где антропогенная нагрузка значительно выше (91,9 \% образцов имеют $\mathrm{P}_{\mathrm{i}}>2$ ), концентрация свинца в почвах повышается с увеличением содержания физической глины, органического вещества и соединений марганца - основных сорбентов тяжелых металлов в верхнем слое почв. Ре-

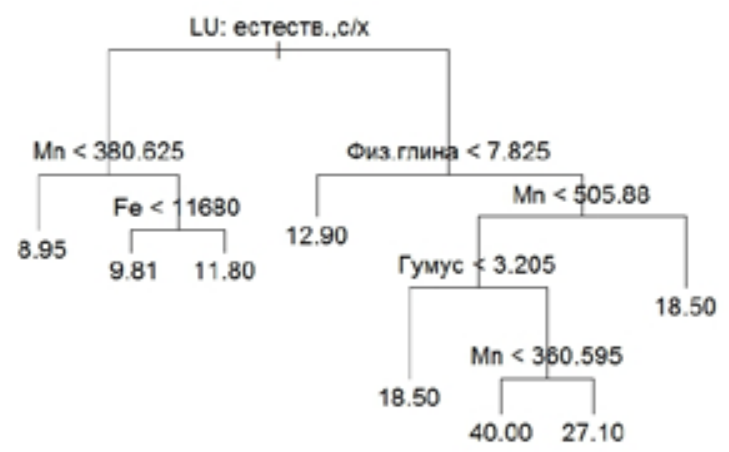

a) $\mathrm{Pb}_{\text {вал. }}$

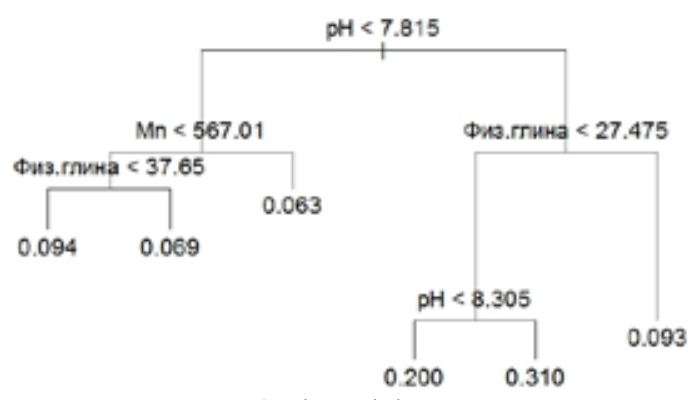

c) $\mathrm{Pb}_{\text {подв. }} / \mathrm{Pb}_{\text {вал. }}$

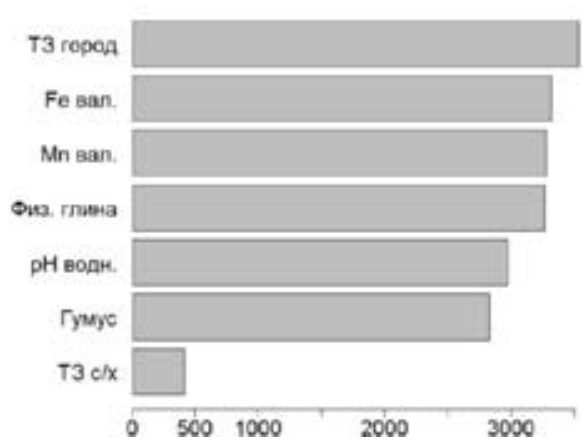

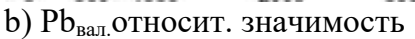

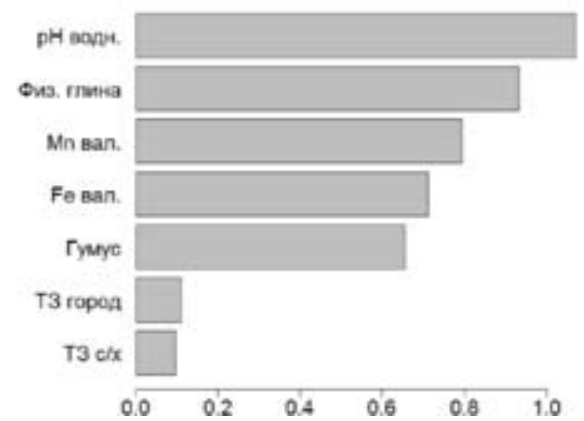

d) $\mathrm{Pb}_{\text {подв. }} / \mathrm{Pb}_{\text {вал. }}$ относит. значимость

Рис. 3. Деревья регрессии и относительная значимость параметров

Fig. 3. Regression trees and relative significance of variables 
зультаты усреднения 10000 регрессионных деревьев, полученные методом RandomForest, подтверждают главенствующую позицию уровня антропогенной нагрузки в определении содержания свинца в почвах, а также высокую значимость гранулометрического состава и соединений $\mathrm{Fe}$ и $\mathrm{Mn}$ в накоплении свинца.

Подвижность свинца во всех типах почв главным образом зависит от актуальной кислотности почвенного раствора: в кислой среде подвижность свинца падает при утяжелении гранулометрического состава и повышении содержания соединений $\mathrm{Mn}$; при повышении $\mathrm{pH}$ подвижность свинца главным образом ограничивается содержанием физической глины (рис. $3 c$ ). Результаты RandomForest подтверждают определяющее влияние актуальной кислотности и гранулометрического состава на подвижность свинца в почвах и меньшее - содержания органического вещества и соединений $\mathrm{Fe}$ и $\mathrm{Mn}$ (рис. $3 d$ ).

\section{Заключение}

Дана характеристика территории с развитым промышленным, нефтедобывающим и сельскохозяйственным секторами в отношении загрязнения почв свинцом. Пространственное распределение содержания свинца в гумусовом горизонте почв имеет неоднородный характер, и, хотя превышение предельно допустимой концентрации в почвах наблюдается лишь для 0,6 \% отобранных образцов, 52,9 \% территории характеризуется как потенциально загрязненная относительно регионального фонового значения. Антропогенный привнос свинца для большей части территории оценивается как незначительный. Будущие работы будут посвящены целенаправленному анализу влияния потенциальных антропогенных факторов на содержание тяжелых металлов в почвах РТ.

Показано отсутствие значимого антропогенного привноса свинца, связанного с сельскохозяйственной деятельностью. Свинец в почвах естественного и с/х типов землепользования зависит от содержания соединений $\mathrm{Fe}$ и $\mathrm{Mn}$, что, совместно с низкими значениями $\mathrm{P}_{\mathrm{i}}$ для данных типов землепользования говорит о преимущественно литогенном происхождении.

В условиях антропогенной нагрузки на городские почвы наблюдаются повышенные значения $\mathrm{P}_{\mathrm{i}}$. Содержание свинца в верхнем слое урбаноземов зависит в первую очередь от гранулометрического состава, содержания органического вещества и соединений марганца, основных сорбентов экзогенного свинца в почвах.

\section{Список литературы}

Александрова А.Б., Бережная Н.А., Григорьян Б.Р., Иванов Д.В., Кулагина В.И. (2012) Красная книга почв Республики Татарстан. Казань, Фолиант, 192 с. [Aleksandrova A.B., Berezhnaya N.A., Grigoryan B.R., Ivanov D.V., Kulagina V.I. (2012) The Red Book of soils of the Republic of Tatarstan. Kazan, Foliant, 192 p. (in Russian)]

Атлас Республики Татарстан (2005) СПБ, ОАО «Иван Федоров», 216 с. [Atlas of the Republic of Tatarstan (2005) St. Petersburg, Ivan Fedorov, 216 p.(in Russian)]

Водяницкий Ю.Н. (2008) Тяжелье металлы и металлоиды в почвах. М., ГНУ Почвенный институт им. В.В. Докучаева РАСХН, 86 c. [Vodyanitskii Yu.N. (2008) Heavy metals and metalloids in soils. Moscow, V.V. Dokuchaev Soil Science Institute of the Russian Academy of Agricultural Sciences, 86 p. (in Russian)] 
Государственный доклад о состоянии природных ресурсов и об охране окружающей среды Республики Татарстан в 2015 году (2015) Министерство экологии и природных ресурсов Республики Татарстан, Казань, 505 с. [State report on the state of natural resources and environmental protection in the Republic of Tatarstan in 2015 (2015) Ministry of Ecology and Natural Resources of the Republic of Tatarstan, Kazan, 505 p. (in Russian)]

Добровольский В.В. (2003) Основы биогеохимии. М., Издательский центр Академия, 342 c. [Dobrovolskii V.V. (2003) Fundamentals of biogeochemistry. Moscow, Academia, 342 p. (in Russian)]

Иванов Д.В. (2016) Разработка региональных нормативов качества почв по содержанию тяжелых металлов. Геохимия ландшафтов. Материаль Всерос. научн. конф. М., Географический факультет МГУ, с. 232-235 [Ivanov D.V. (2016) Development of regional soil quality standards for heavy metals. Geochemistry of landscapes. Materials of Russian Scientific Conference. Moscow, Faculty of Geography, Moscow State University, p. 232-235 (in Russian)]

Кабата-Пендиас А., Пендиас Х. (1989) Микроэлементы в почвах и растениях. М., Мир, 440 c. [Kabata-Pendias A., Pendias H. (1989) Trace ements in soils and plants. Moscow, Mir, 440 p. (in Russian)]

Кауричев И.С., Панов Н.П., Розов Н.Н., Стратонович М.В., Фокин А.Д. (1989) Почвоведение. М., Агропромиздат, 719 с. [Kaurichev I.S., Panov N.P., Rozov N.N., Stratonovich M.V., Fokin A.D. (1989) Soil science. Moscow, Agropromizdat, 719 p. (in Russian)]

РД 52.18.191-89. Методика выполнения измерений массовой доли кислоторастворимых форм металлов (меди, свиниа, ичика, никеля, кадмия) в пробах почвы атомно-абсорбиионным анализом (1990) М., Государственный комитет СССР по гидрометеорологии [Guidance Document 52.18.191-89. Methods of measurement of the mass fraction of acid-soluble forms of metals (copper, lead, zinc, nickel, cadmium) in soil samples by atomic absorption analysis. Moscow, The USSR State Committee for Hydrometeorology (in Russian)]

РД 52.18.289-90. Методика выполнения измерений массовой доли подвижных форм металлов (меди, свинца, циинка, никеля, кадмия, кобальта, хрома, марганца) в пробах почвы атомноабсорбиионным анализом (1991) М., Государственный комитет СССР по гидрометеорологии [Guidance Document 52.18.289-90. Methods of measurement of the mass fraction of mobile forms of metals (copper, lead, zinc, nickel, cadmium, cobalt, chromium, manganese) in soil samples by atomic absorption analysis. Moscow, The USSR State Committee for Hydrometeorology (in Russian)]

Региональные нормативы «Фоновое содержание тяжельх металлов в почвах Республики Татарстан» (2015) Утв. приказом Министерства экологии и природных ресурсов Республики Татарстан от 30.12.2015 №1134-п [Regional standards "Background content of heavy metals in the soils of the Republic of Tatarstan" (2015) Approved by Decree of the Ministry of Ecology and Natural Resources of the Republic of Tatarstan, 30.12.2015 No. 1134-п (in Russian)]

Ягодин Б.А., Дерюгин И.П., Жуков Ю.П. (1987) Практикум по агрохимии. М., Агропромиздат, 512 с. [Yagodin B.A., Deryugin I.P., Zhukov Yu.P. (1987) Practical course of agricultural chemistry. Moscow, Agropromizdat, 512 p. (in Russian)]

Albanese S., De Vivo B., Lima A., Cicchella D., Civitillo D., Cosenza A. (2010) Geochemical baseline and risk assessment of the Bagnoli brownfield site coastal sea sediments (Naples, Italy). Journal of Geochemical Exploration, 105(1-2): 19-33

$$
-115-
$$


Bou Kheir R., Shomar B., Greve M., Greve M. (2014) On the quantitative relationships between environmental parameters and heavy metals pollution in Mediterranean soils using GIS regressiontrees: The case study of Lebanon. Journal of Geochemical Exploration, 147: 250-259

Bradl H.B. (2004) Adsorption of heavy metal ions on soils and soils constituents. Journal of Colloid and Interface Science, 277(1): 1-18

Breiman L. (2001) Random Forests. Machine Learning, 45(1): 5-32

Cambardella C., Moorman T., Novak J., Parkin T., Karlen D., Turco R., Konopka A. (1994) Fieldscale variability of soil properties in Central Iowa soils. Soil Science Society of America Journal, 58(5): $1501-1511$

Covelo E.F., Vega F.A., Andrade M.L. (2007) Competitive sorption and desorption of heavy metals by individual soil components. Journal of Hazardous Materials, 140(1-2): 308-315

Esmaeili A., Moore F., Keshavarzi B., Jaafarzadeh N., Kermani M. (2014) A geochemical survey of heavy metals in agricultural and background soils of the Isfahan industrial zone, Iran. Catena, 121: $88-98$

Goovaerts P. (1997) Geostatistics for natural resources evaluation. Oxford University Press, 497 p.

Hawkes H., Webb J. (1962) Geochemistry in mineral exploration. NewYork, Harper \& Row, 415 p.

Health risks of heavy metals from long-range transboundary air pollution (2007) WHO Regional Office for Europe, $144 \mathrm{p}$.

Isaaks E., Srivastava R. (1989) Applied geostatistics. New York, Oxford University Press, 589 p.

James G., Witten D., Hastie T., Tibshirani R. (2013) An introduction to statistical learning with applications in $R$. London, Springer New York Heidelberg Dordrecht, $440 \mathrm{p}$.

Li W., Zhang X., Wu B., Sun S., Chen Y., Pan W., Zhao D., Cheng S. (2008) A comparative analysis of environmental quality assessment methods for heavy metal-contaminated soils. Pedosphere, 18(3): 344-352

Liaw A., Wiener M. (2002) Classification and Regression by randomForest. $R$ News, 2/3: 18-22

Pebesma E.J. (2004) Multivariable geostatistics in S: the gstat package. Computers \& Geosciences, 30(7): 683-691

QGIS Development Team (2016) QGIS Geographic Information System. Open Source Geospatial Foundation, URL: http://qgis.osgeo.org

$R$ Core Team (2016) R: A Language and Environment for Statistical Computing. R Foundation for Statistical Computing, Vienna, Austria, URL http://www.R-project.org/

Reimann C., De Caritat P. (1998) Chemical elements in the environment. Berlin, Springer-Verlag, $398 \mathrm{p}$.

Ripley B. (2016) tree: Classification and Regression Trees. R package version 1.0-37. URL: https:// CRAN.R-project.org/package $=$ tree

Romic M., Hengl T., Romic D., Husnjak S. (2007) Representing soil pollution by heavy metals using continuous limitation scores. Computers \& Geosciences, 33(10): 1316-1326 